\title{
Erratum to: Early Life Hypoxic or Hypoxic/Hypercapnic Stress Alters Acute Ventilatory Sensitivity in Adult Mice
}

Kui Xu, Solomon Raju Bhupanapadu Sunkesula, Pengjing Huang, Constantinos P. Tsipis, Thomas Radford, Gerald Babcock, Walter F. Boron, and Joseph C. LaManna

\section{Erratum to:}

Chapter 49 in: W.J. Welch et al. (eds.), Oxygen Transport to Tissue XXXIV, Advances in Experimental Medicine and Biology 765, DOI 10.1007/978-1-4614-4989-8_49

The book was inadvertently published with incorrect chapter author information for chapter 49. The author name has been updated as "Bhupanapadu Sunkesula SR".

The updated online version of this chapter can be found at https://doi.org/10.1007/978-1-4614-4989-8_49 